\title{
Entrepreneurship in Family Business: Emerging Storyline 2
}

\author{
Zoheir Ezziane, Elias Mazzawi, and Benoit Leleux
}

\begin{abstract}
Entrepreneurship is a major economic driver in the world. It leads to create jobs as well as wealth. Very little is known about how family businesses ensure that entrepreneurial activity flourishes during the next generations. This paper discusses and analyzes the overlap between family business and entrepreneurship and possibilities of how family businesses initiate entrepreneurial activities. Many interviews were conducted with family business leaders so to understand the nature this engagement. This paper also illustrates and summarizes other cases that lead to valuable lessons and patterns observed in family businesses and how it interacts with entrepreneurship.
\end{abstract}

Index Terms-Family business, entrepreneurship, wealth management.

\section{INTRODUCTION}

The family business literature covers extensively issues surrounding succession and transmission of the family businesses, focusing for example on governance and wealth management for sustainability. One aspect that so far failed to attract much attention is the transmission of the entrepreneurial orientation in these family businesses. Anecdotal evidence abounds as to the inability of succeeding generations to maintain the entrepreneurial drive of the founder. In a 2006 study conducted for the European Venture Capital Association, Leleux and Schwass [1] showed for example that the single family office's willingness to invest in private equity and venture capital was very much inversely correlated to the generational distance to the entrepreneurial founder. In other words, the evidence supported a material drop in the percentage of the investable wealth of the family invested in the riskier asset class when the entrepreneurial founder died. The following generations seemed to have a very hard time perpetuating the entrepreneurial drive of their forefathers.

Even though a definition of a family business is highly contextual, however, it is possible to say that a family business refers to a company where the voting majority is in the hands of the controlling family; including the founder(s)

Manuscript received April 30, 2013; revised June 25, 2013. This work was supported in part by a Wharton grant through the Wharton Entrepreneurship and Family Research Centre, Abu Dhabi, United Arab Emirates.

Zoheir Ezziane is with a Wharton Fellow and a faculty member at the Higher Colleges of Technology, Al Ain Women's College, P.O. Box 17258 Al Ain, UAE (e-mail: zezziane@ @ct.ac.ae).

Elias Mazzawi is with a consultant at EMS MENA FZE, Emirates Towers Level 41, Dubai P.O. Box 31303, UAE.

Benoit Leleux is with Stephan Schmidheiny Professor of Entrepreneurship and Finance at IMD, Ch. de bellrive 23, P.O. Box 915, CH 1001 Lausanne, Switzerland. who intend to pass the business on to their descendants [2]. Fig. 1 represents the intersection of entrepreneurship, family business, and succession.

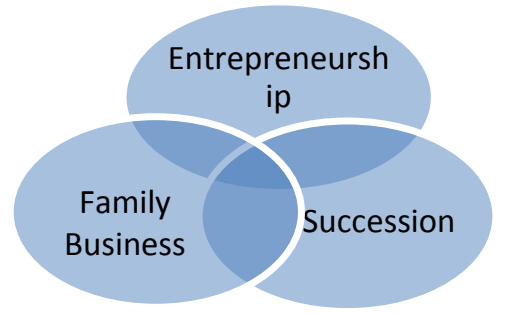

Fig. 1. Entrepreneurship, family business and succession.

The overlaps between the main areas are interesting to investigate and especially the overlap entrepreneurship, family business and succession. Kets de Vries [3] reports that about the $33 \%$ of family businesses survive the first generation and only $10 \%$ make it past the third generation. Similarly, Astrachan and Shanker [4] showcase that 33\% of family business founders make it to the second generation, $12 \%$ reach the third generation, and only $3 \%$ will reach fourth generation.

The longevity of some family businesses is a phenomenon that has fascinated researchers for decades. Some have advanced that to survive over the long term the family firm must be managed with a clear vision of the future of the business and with the intention to pass it on to the next generation [5]. Others focused on the necessity for the family to nurture a shared sense of community between the members of the family and a common desire to remain in business [6]. Some have explored how great family businesses have balanced the needs of the family and those of the business, viewing the equilibrium between these contradictory forces as the key to survival [7].

This paper attempts to follow the footsteps of Zellweger and Sieger [8] that looked at the capacity of the long-lived family firm to maintain an entrepreneurial orientation, or those of Aronoff [9] that focused on the ability of the firm to keep a solid family organization and a good governance structure. The concept of organizational resilience has not been applied much to the study of family businesses, except maybe in Danes et al. [10].

\section{BACKGROUND}

It is of interest to note that, except for the paper of Danes et al. [10], the concept of organizational resilience has not been applied much to the study of family businesses, despite the fact that "sustainability" has garnered a great deal of attention. For example, little seems to be known as to the mechanisms that can insure a proper transmission of the entrepreneurial orientation and talent. Particularly of interest 
will be, in the words of Begin and Chabaud [11], the 'renewal capacity' of the firm, i.e. its ability to act and to devise innovative solutions to meet unusual situations [12]. The 'renewal capacity' is made of inventiveness and innovation, in line with the more generic concepts of the firm's entrepreneurial orientation [13] and the process of strategic regeneration [14], stressing that the organization seeks to develop new activities and / or to restructure existing activities. Based on family entrepreneurship, the renewal capacity suggests looking for opportunities, but also to leave room for initiative taking, innovation and experimentation with new ways of doing things [12].

Following Stopford and Baden-Fuller [14], the emphasis will be put on a few key factors: (1) pro-activity in research opportunities, (2) aspirations that go beyond the current capacity, (3) the mobilization of the management team and employees.

Another related approach is the recent work of Parada et al. [15] motivated by the apparent over-focus of empirical studies on the "bright side" of family involvement [16] showing how these resources lead to competitive advantage and thus become an "asset" over time for the family business. The authors show that family firms heavily rely on active involvement of the founder as CEO, showing entrepreneurial behavior becoming a key resource and competitive advantage. Entrepreneurial behavior was defined as the extent to which firms, through behavior of individuals and teams, increase new product development, facilitate new business creation, and reenergize existing operations [17], as well as their propensity to take risks, to be innovative and to be proactive [18], recognizing opportunities and acting quickly to seize them [19]. Over time these resources can become a "liability", losing the entrepreneurial capacity on the firm level, especially in generational transitions as family and business complexity tend to increase.

This work would seek to investigate the transmission of the entrepreneurial orientation and talent to the next generations in the Arabian Gulf region, focusing in particular on learning mechanisms put in place to offer the next generation opportunities to learn and test their entrepreneurial bends.

\section{RESUlts, ANALYSIS AND DisCUSSION}

\section{A. Facts about Family Business in the Arabian Gulf}

- Family businesses are the main drivers of economic activity, growth and sustainability in many economies all over the world. Davis, Pitss, and Cornier [20] show that family businesses include most of the private sectors of the Gulf economies and represent more than 90 percent of the entire commercial activities in the Gulf Cooperation Council (GCC).

- According to regional experts, family businesses comprise most of the private sectors of the Gulf economies [20]. They also account for over 90 percent of all commercial activities in the GCC, compared to rates ranging from 65 to 80 percent in other regions of the world.
- Osama Al Rahma, Director at Al Fardan Group which is one of the family-owned business conglomerates in the United Arab Emirates (UAE), speaking at the Family Business Forum of the Internal Audit Festival [21] mentioned that only $15 \%$ of family businesses in the UAE would be able to survive the third generation due to the lack of governance structure.

- Sameer Huda, Head of Corporate at Hadef \& Partners in the UAE, speaking at the managing family business workshop in Dubai Chamber [22] argued that "The Middle East is no different from the rest of the world in that dynamic and capable business people establish businesses, some of which have grown to be quite substantial. There is a significant amount of evidence to indicate that a very low percentage of family businesses successfully transition to the second generation, and far fewer manage to survive to the third generation. Those that do survive and thrive tend to have addressed family governance, succession planning, corporate structuring and corporate governance in some meaningful manner

- Family businesses are considered a key economic driver in the GCC. According to the Dubai International Financial Center, family businesses control more that 90 percent of all commercial activities. The number of these firms was estimated at 5000 holding combined assets of more than $\$ 500$ billion, and employ about 70 percent of the workforce. In addition, Nasser Said, DIFC Chief Economist pointed out that families hold two-thirds of the boards of UAE listed companies where multiple family members on the board of same company [23].

\section{B. Interview Results}

To date we have interviewed a handful of companies, in Dubai. We have some interesting initial findings. A number of observations that resulted from ours interviews are as under:

- A range of views on the importance of entrepreneurship over the next decade. Companies have very different strategic aspirations.

1) At the most conservative, companies are seeking to preserve cash and maintain their current positions.

2) Others are looking to float the businesses on the public markets when conditions are favorable.

3) These attitudes drive both attitude and approach to entrepreneurship, and to the importance of generational transition of entrepreneurship.

- In some cases, a lack of clarity on who is responsible for entrepreneurship. We encountered the following situations during our interviews:

1) In one organization, the real driver of entrepreneurship is the founder. This is then passed to a corporate development unit to review and develop strategic initiatives.

2) We have seen a corporate venturing unit, to incubate and develop businesses linked to the core family business. Run as an in-house private equity unit. Typically early stage strategic diversifications, likely to 
have a 'cap' on potential scale - of a relatively small percentage of the overall business.

3) In another, entrepreneurship is implicitly (not explicitly) passed to the annual budget / planning process. Family members, who run operating units, put forward their plans to grow the business. Limited ambition entrepreneurship - extensions from current business not step-change expansion / diversification.

4) In another, the emphasis seems to be a mix of entrepreneurship through the family office - acquiring 'challenged' companies and some through the core business where there is a direct link to core business activity.

5) In another, entrepreneurship seems to be translated into increasingly challenging targets for the core business rather than diversification geographically or by product. This is passed to existing management, irrespective of generation.

We have so far heard limited focus on generational change and entrepreneurship. We don't have a clear picture emerging of how the linkage between 'family' and 'employed' management and the business will play out as generations change. Perhaps this will, in part, be determined by how business ownership changes as companies IPO, when practical.

We are forming an impression of 'command and control' management structures - with tightly held reins in the hands of the founding generation. With an impression that the founding generation remains in the business beyond typical Western retirement age. And thus maintaining very strong influence over the business. Potentially implying that true generational transition takes place when the 'heirs' are perhaps older than business leaders in the West?

We would like to investigate the extent to which succeeding generations take on 'staff' roles such as corporate development, sales/business development, geographic expansion roles (as MDs of businesses expanding into new geographies), or diversification / expansion roles (again as MDs). To date, we have not found substantial examples of succeeding generations taking on these roles, in an actively/ambitiously entrepreneurial environment.

We have been told that the 'in principle' approach for a specific firm is for family members to be given an opportunity to test the waters and their leadership skills through leading one of the family business projects. Subsequently, if a reasonable success comes out of this experience, then this person would be given the opportunity not only to be part of the family business executive council but also shape up the vision of the entire family business. We do not have specific examples to refer to - to better understand how this is shaped and what results have been.

\section{CONCLUSION}

Businesses in general should have a corporate governance structure to foster viability and sustainability. The role of governance structure and its impact on family businesses control the type of entrepreneurship which could be planned and conducted. This opens up an opportunity to investigate the correlation between the type of family governance system and the entrepreneurship drive in the family business.

\section{ACKNOWLEDGMENT}

This work was supported by a Wharton grant funded by the Wharton Entrepreneurship and Family Business Research Centre at CERT in Abu Dhabi, UAE.

\section{REFERENCES}

[1] B. Leleux, J. Schwass, and A. A. Diverse, Europe's Family Offices, Private Equity and Venture Capital. An European Private Equity and Venture Capital Association (EVCA) Special Report, 2007.

[2] S. Abouzaid, IFC Family Business Governance Handbook, International Finance Corporation, 2008.

[3] K. D. Vries and F. R. Manfred, "The dynamics of family controlled firms: The good and the bad news," Organizational Dynamics, vol. 21, no. 3, pp. 59-71, 1993.

[4] J. H. Astrachan and M. C. Shanker, "Family businesses' contribution to the U.S. economy: A closer look," Family Business Review, vol. 16, no. 3 , pp. $211,2003$.

[5] K. E. Gersick, J. A. Davis, H. M. McCollom, and I. Lansberg, Generation to generation: Life Cycles of the Family Business. Boston, MA: Harvard Business Press, 1997.

[6] E. Santarelli and F. Lotti, "The survival of family firms: the importance of control and family ties," International Journal of Economics of Business, vol. 12, no. 2, pp. 183-192, 2005.

[7] J. L. Ward, Keeping the family business healthy, San Francisco, CA: Jossey-Bass, 1987.

[8] T. Zellweger and P. Sieger, "Entrepreneurial orientation in long-lived family firms," Small Business Economics, vol. 38, no. 1, pp. 67-84, 2010 .

[9] C. Aronoff, "The self-perpetuation family organization built on values: necessary condition for long term family business survival," Family Business Review, vol. 17, no. 1, pp. 55-59, 2004.

[10] S. M. Dane, J. Lee, S. Amarapurkar, K. Stafford, G. Haynes, and K. E. Brewton, "Determinants of family business resilience after a natural disaster by gender of business owner," J. Dev. Entrepreneurship, vol. 14, no. 4, pp. 333-354, 2009.

[11] L. Bégin and D. Chabaud, "Bouncing back and going on: the resilient family firm. Cahier de recherches 70," presented at the EIASM 6th Workshop on Family Firms Management Research, Barcelona (Spain), ESADE University, June 6-8 ${ }^{\text {th }}, 2010$.

[12] C. A. Lengnick-Hall and T. E. Beck, "Resilience capacity and strategic agility: prerequisites for thriving in a dynamic environment," in Resilience Engineering Perspectives, vol. 2, Preparation and Restoration. Ed. C.P. Nemeth, E. Hollnagel, \& S. Dekker. Burlington, VT: Ashgate Publishing Company, 2009.

[13] H. E. Stevenson and J. C. Jarillo, "A paradigm of entrepreneurship: Entrepreneurial management," Strategic Management Journal, vol. 11, pp. 17-27, 1990.

[14] J. M. Stopford and C. W. Baden-Fuller, "Creating corporate entrepreneurship," Stra. Man. J., vol. 15, no. 7, pp. 521-536, 1994.

[15] M. J. Parada, A. Gimeno, and L. Melin. (2010). Familiness: An asset or a Liability? [Online]. Available: http://www.lums.lancs.ac.uk/files/familybusiness/20104.pdf.

[16] A. Minichilli, G. Corbetta, and I. C. MacMillan, Top Management Teams in Family-Controlled Companies: Familiness, Faultines, and Their Impact on Financial Performance, J. Man. Studies, vol. 47, no. 2, pp. 205-222, 2010.

[17] G. Pinchot, Intrapreneuring: Why You Don't Have to Leave the Corporation to Become Entrepreneur, Harper and Row Publishers, New York, NY, 1985.

[18] K. M. Green, J. G. Covin, and D. P. Slevin, "Exploring the relationship between strategic reactiveness and entrepreneurial orientation: the role of structure - style fit," Journal of Business Venturing, vol. 23, no. 3, pp. 356-83, 2008.

[19] S. A. Alvarez and J. Barney, "Discovery and creation: alternative theories of entrepreneurial action," Strategic Entrepreneurship Journal, vol. 1, no. 11, pp. 11-26, 2007.

[20] J. Davis, E. Pitts, and K. Cormier, "Challenges Facing the Family Companies in theGulf Region," Family Business Review, vol. 13, no. 3, pp. 217-238, 2000.

[21] O. Al Rahma. (20th December 2011). Family Owned Business and Internal Audit Function. Presented at Dubai Chamber. [Online]. Available: http://iiauae.org/pdf/26-12-2011/fobs_internal_audit.pdf 
[22] Dubai Chamber. (2012). Managing family business. [Online]. Available:

http://www.dubaichamber.com/news/managing-family-business-is-th e\%E2\%80\%A8highlight-of-dubai-chamber-workshop

[23] K. R. Listana. (2010). Family businesses 'need to preserve wealth'. Emirates 24/7. [Online]. Available: http://www.emirates247.com/eb247/economy/regional-economy/fami ly-businesses-need-to-preserve-wealth-2010-05-26-1.248362

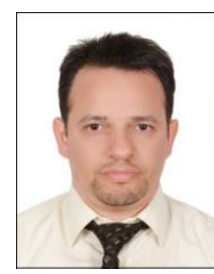

Zoheir Ezziane is a Ph.D. in technology and operations management from Florida Atlantic University in 1994. He is a former research fellow at Harvard, Oxford, Imperial College, and Stanford. His current research interests include operations management, healthcare management, IT, family business and entrepreneurship. $\mathrm{He}$ is currently a Wharton Fellow and a faculty member at the Higher Colleges of Technology, Al Ain, UAE. He published over 35 peer-reviewed papers in refereed international conferences and peer-reviewed journals.

Elias Mazzawi is a consultant at EMS MENA FZE, Emirates Towers Level 41, Dubai P.O. Box 31303, UAE.

Benoit Leleux is Stephan Schmidheiny Professor of Entrepreneurship and Finance at IMD, Ch. de bellrive 23, P.O. Box 915, CH 1001 Lausanne, Switzerland. 